\title{
Brain death in a neurologic intensive care unit in turkey
}

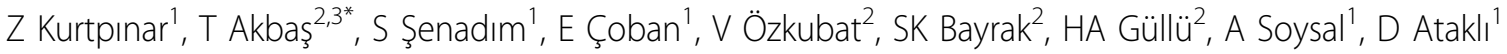 \\ From ESICM LIVES 2015 \\ Berlin, Germany. 3-7 October 2015
}

\section{Introduction}

The diagnosis of brain death (BD) is important in order to decrease the burden of futile care and procure vital and viable organs for donation. The aim of this study was to find clinical features of patients, diagnostic tools used, attitude to $\mathrm{BD}$ and donation rate in a teaching hospital for neurologic diseases in Istanbul.

\section{Methods}

All consecutive BD patients between April 2014-April 2015 were included in this retrospective study. Data were abstracted from medical records. Statistical analyses were performed using SPSS software. The results were expressed as percentages for categorical data and median with interquartile range for continuous variables.

\section{Results}

Twenty-three patients [10F/13M, age: 63 (54-75)] had BD diagnosis. Neurologic etiologies were ischemic stroke (52\%), intracranial bleeding (39\%), hypoxic encephalopathy (4.5\%) and transverse sinus thrombosis (4.5\%). The Glasgow Coma Scales (GCS) were 9 (5-11) at hospital and 7 (5-9) at ICU admission. The clinical sign encouraging the clinicians to think BD were brain stem areflexia (39\%), decreased GCS (34.5\%), absence of spontaneous breathing (17.5\%) and polyuria (9\%). BD was suspected first by ICU physicians in 56.5\%. BD diagnosis was delayed for $>12$ hours in 11 patients because of being sure about BD (46\%), legal observation time (27\%), sedation (18\%) and hemodynamic instability (9\%). Fifteen patients had BD diagnosis with apnea and brainstem testing. The remaining 8 cases had confirmatory diagnostic evaluations of BT angiography (6) and EEG (2) due to inability of performing apnea testing (5), clinical suspicion (2) and uncomfortable

${ }^{2}$ Bakirkoy Research and Training Hospital for Psychiatry, Neurology and Neurosurgery, Intensive Care Unit, Istanbul, Turkey

Full list of author information is available at the end of the article feeling in giving the decision (1). Apnea testing was reported before neurologic examination in $26 \%$. No complication was documented during apnea testing. Diabetes insipidus was developed in $78 \%$ and desmopressin was given to $39 \%$ of polyuric patients. Vasopressors were ordered to $95.5 \%$ [Noradrenaline (68\%), dopamine (18\%) and both drugs (14\%)] and methylprednisolone [60 (36$60) \mathrm{mg} /$ day] to $57 \%$. Levothyroxine [300 $(112-400) \mathrm{mcg}]$ was ordered only one time to $39 \%$ during the $\mathrm{BD}$ diagnosis period. Three (13\%) patients were allowed to be donors by the relatives. The therapy was withdrawn in $55 \%$ and held on the present support until cardiac arrest in $35 \%$ of the nondonors. No information was found for $10 \%$ of the nondonors. The time span from BD confirmation to cardiac arrest developed was $120(60-636)$ minutes for the nondonors.

\section{Conclusions}

The main clinical signs encouraging the clinicians to identify brain death are brainstem areflexia and decrease in GCS. Apnea and brain stem testing are the major diagnostic approach. Diabetes insipidus and hypotension are commonly encountered situations in these patients.

\section{Competing interests}

No conflict of interest was declared by the authors.

\section{Authors' details}

${ }^{1}$ Bakirkoy Research and Training Hospital for Psychiatry, Neurology and Neurosurgery, Istanbul, Turkey. ${ }^{2}$ Bakirkoy Research and Training Hospital for Psychiatry, Neurology and Neurosurgery, Intensive Care Unit, Istanbul, Turkey. ${ }^{3}$ Düzce University, School of Medicine, Internal Medicine and Intensive Care Unit, Duzce, Turkey.

Published: 1 October 2015

\section{Reference}

1. Shappell CN, Frank JI, Husari K, Sanchez M, Goldenberg F, Ardelt A: Practice variability in brain death determination: a call to action. Neurology 2013, 81(23):2009-14. (c) 2015 Kurtpınar et al.; This is an Open Access article distributed under the terms of the Creative Commons Attribution License (http:// creativecommons.org/licenses/by/4.0), which permits unrestricted use, distribution, and reproduction in any medium, provided the original work is properly cited. 
doi:10.1186/2197-425X-3-S1-A987

Cite this article as: Kurtpınar et al:: Brain death in a neurologic intensive care unit in turkey. Intensive Care Medicine Experimental 2015 3(Suppl 1): A987.

\section{Submit your manuscript to a SpringerOpen ${ }^{\circ}$ journal and benefit from:}

- Convenient online submission

- Rigorous peer review

- Immediate publication on acceptance

- Open access: articles freely available online

- High visibility within the field

- Retaining the copyright to your article

Submit your next manuscript at $\gg$ springeropen.com 